\title{
Does Rest Period After Warming Up Have an Effect on Swimming Performance? ${ }^{1}$
}

DOI: $10.26466 /$ opus.951294

\author{
Yücel İnaç - Tülin Atan ${ }^{* *}$ - Şaban Ünver ${ }^{* * *}$ \\ *Specialist, Ondokuz Mayıs University, Samsun/Turkey \\ E-Mail: inacyuce@gmail.com ORCID: 0000-0002-4093-1462 \\ ** Prof. Dr, Universty of Ondokuz Mayıs, Faculty of Sport Sciences, Samsun/Turkey \\ E-Mail: takman@omu.edu.tr \\ ORCID: 0000-0001-5660-8910 \\ *** Asst. Prof. Dr., Universty of Ondokuz May1s, Faculty of Sport Sciences, Samsun/Turkey \\ E-Mail: saban.unver@omu.edu.tr \\ ORCID: $\underline{0000-0001-7378-596 X}$
}

\begin{abstract}
The purpose of this study is to evaluate the effects of different rest periods after the warm-up (WU) done before a swimming performance.Eighteen licensed male swimmers in Samsun's swimming clubs who have been at least three years in active swimming and training with a minimum of 4 days a week; voluntarily participated in this study. After doing land and water WU, athletes rested $10 \mathrm{~min}, 20 \mathrm{~min}, 30 \mathrm{~min}$ or $40 \mathrm{~min}$ (on different days) before swimming performance. The swimming performance values of the athletes were measured at distances of $50 \mathrm{~m}$ or $400 \mathrm{~m}$. Each athlete had the test within eight separate days (resting $10 \mathrm{~min}, 20 \mathrm{~min}$, $30 \mathrm{~min}$ or $40 \mathrm{~min}$ ), with a total of 4 times $50 \mathrm{~m}$ and 4 times $400 \mathrm{~m}$. The measurements were carried out at the Olympic swimming pool of Ondokuz Mayıs University. Statistical analysis of the collected data was done using the Friedman test and Wilcoxon sign rank test.Findings show that postWU rest periods of $10 \mathrm{~min}, 20 \mathrm{~min}, 30 \mathrm{~min}$ and $40 \mathrm{~min}$, did not have any significant effect on the $50 \mathrm{~m}$ swimming performance values of the athletes $(p>0.05)$, while, a statistically significant effect $(p<0.05)$ was found in performance values when the athletes applied the post-WU rest periods in $400 \mathrm{~m}$ swimming distance. Additionally, according to the rest periods post-WU, it was determined that there was no statistically significant difference between the heart rate (HR) values after a $50 \mathrm{~m}$ swimming distance ( $p>0.05$ ), while it seemed to affect the HR values after $400 \mathrm{~m}$ distance $(p<0.05)$.Rest periods post-WU do not affect the $50 \mathrm{~m}$ swimming performance. However, 40 minutes rest time postWU enhances the $400 \mathrm{~m}$ swimming performance. Concurrently, a higher performance after a 40 min rest period results in higher HR values after a $400 \mathrm{~m}$ swimming. In conclusion, we conclude that post-WU rest time does not affect the 50 $m$ and $400 \mathrm{~m}$ freestyle swimming performance. However, at $400 \mathrm{~m}$ swimming distances, increasing the rest time postWU improves swimming performance.
\end{abstract}

Key Words: Swimming, Warm-up, Rest Periods.

\footnotetext{
${ }^{1}$ This study was produced from the master's thesis titled "The effect of rest time after warn up on swimming performance".
} 


\title{
Isınmadan Sonra Dinlenme Süresinin Yüzme Performansı Üzerinde Bir Etkisi Var mıdır?
}

\section{Öz}

\begin{abstract}
Bu çalışma yüzme müsabakası öncesi yapılan ısınmanın sonrasındaki dinlenme süresinin performans üzerindeki etkisini incelemek amacıyla yapılmıştır.Çalışmaya, Samsun'da bulunan yüzme kulüplerine lisanslı olarak devam eden ve en az 3 yıl aktif spor (yüzme) yaşantısı olan haftada en az 4 gün antrenman yapan 18 erkek yüzü̈cü gönüllü olarak katılmıştır. Çalışmaya katılan sporcular araştırmacılar tarafindan hazırlanan kara ısınması ve su içi ısınması yaptıktan sonra farklı günlerde 10dk, 20dk, $30 \mathrm{dk}$ veya 40dk dinlendirilerek, sporcularm rastlantısal şekilde $50 \mathrm{~m}$ veya $400 \mathrm{~m}$ yüzme performansları ölçülmüş̧ür. Her sporcu 4 farkl günde olmak üzere toplam $8 \mathrm{kez}(50 \mathrm{~m}$ ve $400 \mathrm{~m}$ ) teste tabi tutulmuştur. Ölçümler Ondokuz Mayıs Üniversitesi Olimpik yüzme havuzunda gerçekleştirilmiştir. Verilerin istatistiksel analizinde Friedman testi ve Wilcoxon işaret sıra sayıları testi kullanılmıştır. Sporcuları ısınma sonrası 10dk, 20dk, 30dk ve 40dk bekleme sürelerinin $50 \mathrm{~m}$ yüzme performansı üzerinde istatistiksel olarak anlaml düzeyde etkisi olmadığı $(p>0,05)$, ancak $400 \mathrm{~m}$ yüzme dereceleri incelendiğinde dinlenme sürelerinin yüzme performansını istatistiksel olarak anlaml düzeyde etkilediği tespit edilmiştir $(p<0,05)$. Sporcuların ısınma sonrası dinlenme sürelerine göre, 50 m yüzme sonrası Kalp Atım Hızı (KAH) değerleri arasında istatistiksel olarak anlaml farklılık olmadı̆̆ $(p>0,05)$ fakat 400 m yüzme sonrası KAH değerlerini etkilediği tespit edilmiştir $(p<0,05)$. Isınma sonrası bekleme süresi $50 \mathrm{~m}$ yüzme performansinı etkilememektedir. Isınma sonrası bekleme süresi 40dk'ya çıkarıldığııda; 400 m yüzme performansı artmaktadır. Bununla bağlantılı olarak, 40dk bekleme sonrası daha yüksek performans sergilenmesi, 400 m yüzme sonrası KAH'ını da daha yüksek çıkmasına neden olmuştur. Sonuç olarak, ısınma sonrası dinlenme süresi, 50 m'ye kadar olan kısa mesafe yüzme performansını etkilemez. Ancak yüzme mesafesi uzadıkça dinlenme süresinin de artması performansta iyileşme sağlamaktadır.
\end{abstract}

Anahtar Kelimeler: Yüzme, Isınma, Dinlenme Süresi. 


\section{Introduction}

Warm-up is generally defined as the physical activity done before the main event and meant to prepare the athlete to perform and increase athletic performance (Hedrick, 1992, p.25). Nowadays, whether it is a sports activity for well-being, a performance sport or training for that sport, the first activity to encounter in a competition or training session is WU (Kuter and Ozturk, 1997, p.35). WU is considered one of the most crucial factors known to improve training and competition, leading to optimal athletic performance (Ballionis, Nepocatych, Ellis, Richardson, Neggers and Bishop 2012, p.485). The WU intends to enhance muscle and tendon mobility, accelerate blood flow and increase muscle temperature (Smith, 2004, p.13). During WU, activation and continuous movements of the muscle facilitate the transition from resting to exercise state. Additionally, pre-engaging muscles in WU activity reduces the risk of injury (Woods, Biskop and Jones, 2007, p.1090). With WU, athletes are prepared physically and psychologically in the most appropriate way that matches specified tasks, which eventually enhance the coordination of target-oriented movements (Sevim, 2007, p.296).

The WU intends to increase the body's temperature, especially within the muscles. Apparently, in events that start without proper WU, blood circulation decreases as a result of the vasoconstriction due to the low body temperature below $37^{\circ} \mathrm{C}$ (Gunay and Yuce, 2008, p.235). Resulting in decreases in the amount of nutrient carried to the tissues, which negatively affect athletic performance.

Swimming is a sport by which milliseconds counts when winning a race. Therefore, it is profound to identify specific factors that increase performance at each phase of WU, training, and competitions (Agopyan, Bozdogan, Tekin, Yetkin and Guler, 2012, p.494). As in different sports branches, WU is the first work to be done when seeking to increase swimming training and performance.

Scientific research has proven that pre-competition WU has an effect on performance. However, reviewing the literature of swimming research, no study or any source of knowledge has been observed to examine the length of post-WU rest time and its positive impact on swimming performance. Therefore, we can say that this study is peculiar in this respect. The aim is to resolve gaps in the literature and provide athletes and coaches with critical 
information. Furthermore, it can guide investigators in this area for future research. The purpose of this study to examine the length of different rest period post-WU \& their impact on swimmers' performance is substantial.

This study was designed with the hypothesis of how different rest periods after warming up in swimming will reflect on performance. Considerably, in most competing conditions, athletes are given a specific duration to first WU for once in the same pool where the competition is running. In such circumstances, where there is no spare WU pool where the competition is taking place, swimmers after their WU have to wait outside the pool until race time before entering the water again. We examine the implications of this situation on performance in this study and evaluate different rest periods post-WU influence on swimmers' performance.

\section{Material and Method}

Subjects: Eighteen male trained swimmers licensed for at least three years between 13 and 15 years of age volunteered to participate in the study. The participants trained at least four times a week during the duration of this study and had been involved in competitive swimming tournaments with national championships of Samsun province in Turkey. The study was conducted following the rules of Ondokuz Mayis University KAEK 2018/349 ethics committee.

Study Design: Familiarizing the athletes with the devices used in the study and giving them the necessary information about the measurement processes, was ensured before starting the study. Athletes participated in trial measurements on a different day before the actual test day to assure obtaining reliable results from the measurement processes and to eliminate the fatigue factor of the subjects. The study measurements were carried out at the Olympic swimming pool of Ondokuz Mayis University. The participants' physical characteristics such as age, height and body weight values were collected. The study design is given in the flow chart below. 


\begin{tabular}{l}
\hline Step 1 \\
\hline Land Warming Training \\
(15min) \\
\hline * laps of light tempo run \\
around a 50x25 m pool \\
* Burpee (10 Times) \\
* Squat (10 Times) \\
* Mountain Climbs \\
Forward/Backward arm \\
movements
\end{tabular}

\begin{tabular}{|c|c|}
\hline Step 2 & Step 3 \\
\hline $\begin{array}{l}\text { Water Warm Up } \\
\text { Training } \\
\text { (One of the following } \\
\text { warm-ups will be } \\
\text { applied for each meas- } \\
\text { urement) }\end{array}$ & $\begin{array}{l}10 \mathrm{~min} / 20 \mathrm{~min} / 30 \mathrm{~min} \\
\text { or } 40 \mathrm{~min} \text { rest }\end{array}$ \\
\hline $\begin{array}{l}\text { Warm-up before } 50 \mathrm{~m} \\
\text { freestyle swimming } \\
\text { performance: (15min) } \\
* 200 \mathrm{~m} \text { freestyle } \\
\text { swimming } 45 \mathrm{sec} \text { rest } \\
* 2 \times 100 \mathrm{~m} \text { ( } 25 \mathrm{~m} \text { foot / } \\
50 \mathrm{~m} \text { right-left arm } \\
\text { drills / } 25 \mathrm{~m} \text { freestyle) } \\
45 \text { sec rest } \\
* 4 \times 50 \mathrm{~m} \text { ( } 25 \mathrm{~m} \text { fast } / 25 \\
\mathrm{~m} \text { slow free swimming) } \\
45 \text { sec rest } \\
* 100 \mathrm{~m} \text { cooling float } \\
\text { Warm-up before } 400 \mathrm{~m} \\
\text { freestyle swimming } \\
\text { performance: }(25 \mathrm{~min}) \\
* 300 \mathrm{~m} \text { freestyle swim- } \\
\text { ming } 45 \text { seconds rest } \\
* 2 \times 100 \mathrm{~m} \text { ( } 25 \mathrm{~m} \text { foot } / 50 \\
\text { m right-left arm drill / } \\
25 \mathrm{~m} \text { free swimming) } \\
45 \text { sec rest } \\
* 4 \times 100 \mathrm{~m} \text { fast free } \\
\text { swimming } 2 \text { minutes } \\
\text { rest } \\
100 \mathrm{~m} \text { cooling float }\end{array}$ & $\begin{array}{l}\text { The athletes rested for } \\
\text { the specified time } \\
\text { before performance }\end{array}$ \\
\hline
\end{tabular}
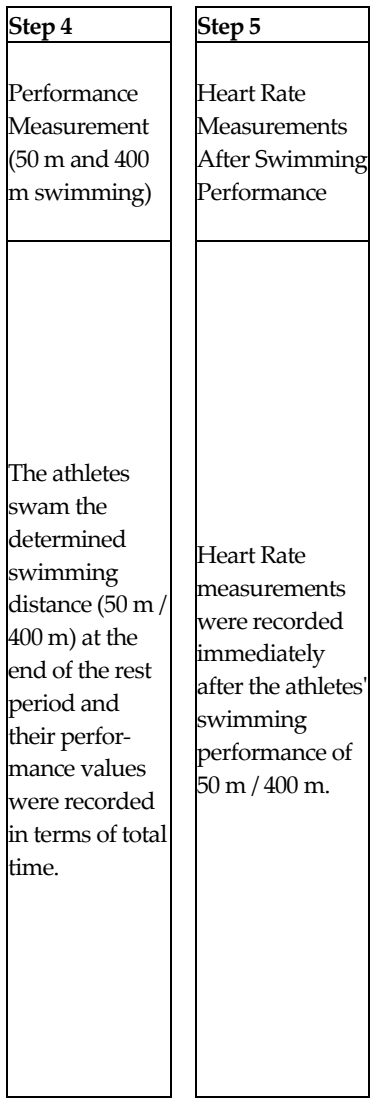

Figure 1. Flow chart of the study

Note: For this study, an athlete performed 4 times $50 \mathrm{~m}$ (10 min / $20 \mathrm{~min} / 30 \mathrm{~min}$ and 40 min rest), 4 times $400 \mathrm{~m}$ (10 min / $20 \mathrm{~min} / 30 \mathrm{~min}$ and $40 \mathrm{~min}$ rest) on different days.

Statistics: SPSS 21 package program was used in the statistical analysis of the data. The Shapiro Wilk test was used to check whether the data showed normal distribution. Since the data did not show a normal distribution, the Friedman test was used to examine the differences between swimmers' performance values measured after four different resting periods. The Wilcox- 
on sign rank test was used to determine which resting times have shown any difference.

\section{Results}
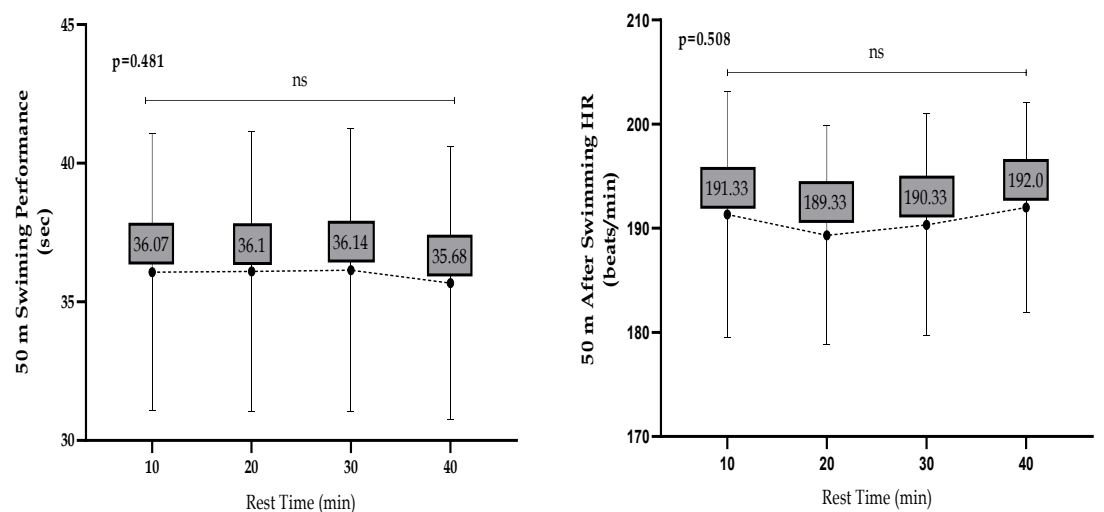

Figure $2.50 \mathrm{~m}$ swimming performance values and HR values after different rest periods $\mathbf{n s}=$ non-significant, $\mathbf{m i n}=$ minute, $\mathbf{s e c}=$ second, $\mathbf{H R}=$ Heart Rate, $\mathbf{m}$ $=$ meter

The $50 \mathrm{~m}$ (duration) swimming performance according to different rest periods (10 $\mathrm{min}, 20 \mathrm{~min}, 30 \mathrm{~min}, 40 \mathrm{~min}$ ) and HR values after this performance are presented in Figure 2. It was found that post-WU rest periods of 10, 20, 30 and 40 minutes did not have a statistically significant effect on the $50 \mathrm{~m}$ swimming performance ( $\mathrm{p}>0.05$ ). It was found that there was no statistically significant effect on HR values measured after swimming $(\mathrm{p}>0.05)$. 

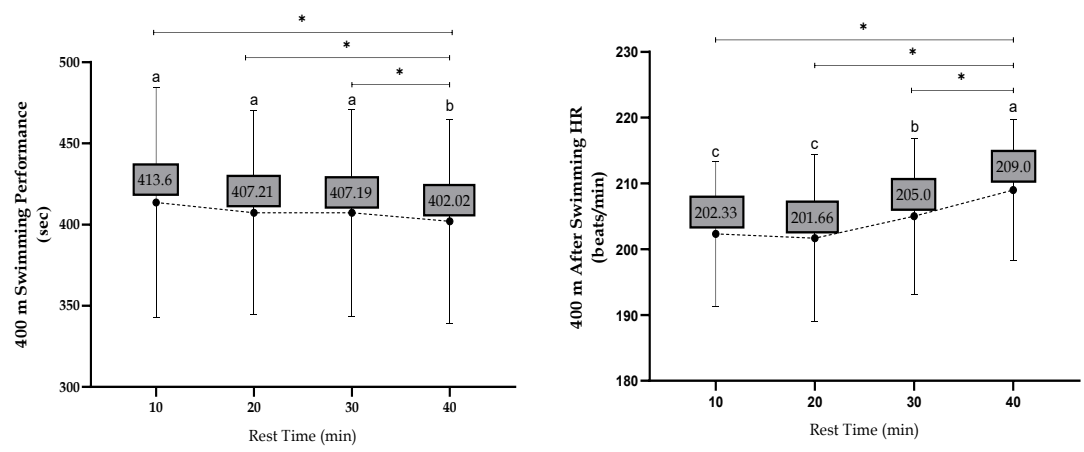

Figure 3. $400 \mathrm{~m}$ swimming performance grades and HR values after different rest periods

${ }^{*} p<0.05$, min $=$ minute, sec $=$ second, $H R=$ Heart Rate,$m=$ meter

Figure 3 shows the swimming performance of $400 \mathrm{~m}$ (duration) according to different rest periods (10 $\mathrm{min}, 20 \mathrm{~min}, 30 \mathrm{~min}, 40 \mathrm{~min}$ ) and HR values after this performance. When the $400 \mathrm{~m}$ swimming measurements were examined after different rest periods, it was determined that the rest period had a statistically significant effect on the $400 \mathrm{~m}$ swimming performance $(p<0.05)$. When swimmers were given a 40 minutes rest period, they showed better performance than the other resting periods $(p<0.05)$. Additionally, a statistically significant difference was found in HR values measured after $400 \mathrm{~m}$ swimming performance post different rest periods $(\mathrm{p}<0.05)$. It was determined that the HR values measured after $400 \mathrm{~m}$ swimming performance resting 40 minutes post-WU were statistically significantly higher than the HR values measured after the performance after all the other rest periods (10 minutes, 20 minutes and 30 minutes) $(\mathrm{p}<0.05)$. Likewise, it was determined that the HR values measured after the $400 \mathrm{~m}$ swimming by resting for 30 minutes post-WU were statistically significantly higher than the HR values measured after the performance of 10 and 20 minutes rest $(\mathrm{p}<0.05)$. 


\section{Discussion, Conclusion and Recommendation}

The purpose of this study was to examine the effect of rest periods (10 $\mathrm{min}$, $20 \mathrm{~min}, 30 \mathrm{~min}$ and $40 \mathrm{~min}$ ) post-WU before the swimming performance (50 $\mathrm{m}$ and $400 \mathrm{~m}$ ).

$50 \mathrm{~m}$ and $400 \mathrm{~m}$ swimming performances (duration) and HR values measured after swimming; were compared according to post-WU rest periods of the subjects. It was found that different post-WU rest periods before swimming, did not have a statistically significant effect on the $50 \mathrm{~m}$ swimming performance and HR values. In other words, after all different rest periods post $\mathrm{WU}, 50 \mathrm{~m}$ swimming performance and the $\mathrm{HR}$ values measured after this performance were similar to each other.

Since $50 \mathrm{~m}$ swimming is a short distance, rest periods may not affect short distance swimming performance. This finding of our study was supported by another study found in the literature (Turkmen, 2019, p.35). In another attempt to determine the effects of different time intervals on repetitive swimming performances post-WU, a study evaluated the contribution of active rest types performed during these periods. Participants were nine active swimmers involved in competitive swimming and continuous training with an average age of 16 . The study determined no significant statistical effect of rest periods on performance. However, it has been stated that the most effective rest interval in terms of repetitive swimming performance is 30 minutes, with the fact that swimmers stop warming up 30 minutes before the start of the competition may have positive effects on performance (Turkmen, 2019, p.35).

Since there are no studies similar to ours in the literature, we examined studies investigating the effect of resting time post-WU from different branches (Galazoulas and Tzimou 2012; Alber and Annoni, 2014; Coskun, 2017). One study examined the effects of rest periods of 4,8 and 12 minutes on vertical jump performance. It concluded that performance was higher after 4 minutes of rest when compared to 8 and 12 minutes of rest periods (Ryan, Lowery, Nevine, Duncan and Jeremy, 2012, p.3320). Similarly, a study conducted by basketball players examined passive rest intervals of 10 , 20,30 and 40 minutes post-WU. Found a decrease of approximately $15 \%$ in the jumping performance of the athletes in the 20th minute. In the same study, the author reported that the group standing without doing any activ- 
ity during the 20-minute rest period post-WU had better jumping performance than the group that did inactive sitting (Alberti, Annoni, Ongaro, Scurati and Michielon, 2014, p.85). In another study that observed a gradual decrease in athletes' jumping performance, the author referred that after 40 minutes of passive rest, there was a $20 \%$ decrease in jumping performance and a $6 \%$ decrease in sprint performance (Galazoulas, Tzimou, Karamousalidis and Mougios, 2012, p.30). The findings of these studies that examined athletes jumping efficiency are different from the results of this study. The reason for the different results is thought to be due to the difference in the measured motor feature.

As determined in this study, the resting time post-WU had a statistically significant effect on both the $400 \mathrm{~m}$ swimming performance and the HR values measured afterwards. Besides, increasing the resting time up to 40 minutes is thought to have a distinguished effect on performance due to the more time allowed to remove LA formed in the muscles after WU. According to Sahlin (1992, p.99), the recovery time from the maximum lactate concentration to the standard levels is 30-60 minutes. In our study, the subject completed 15 minutes on land and 25 minutes in the pool water, a total of 40 minutes WU pre-starting the $400 \mathrm{~m}$ swimming performance. That may cause the subjects to get tired and increase the amount of LA. Obviously, after 40 minutes rest period post-WU, LA amount will further reduce than from a $10 \mathrm{~min}$ rest. Ensure enough time for the body to rest and even perform better. In a previous study it was reported that the maximum blood lactate concentration value reached $10.0 \pm 1.25 \mathrm{mmol} / \mathrm{L}$ after a test and dropped $2.87 \pm 0.91 \mathrm{mmol} / \mathrm{L}$ after $60 \mathrm{~min}$ posttest. A study considered the difference in LA concentration as the indicator of the participants' rate of removal of lactate from the blood. The average rate of lactate elimination per minute (recovery rate) for 1 hour after loading was $0.12 \pm 0.03 \mathrm{mmol} / \mathrm{L}$. As a result, the best time to start a second activity can be considered with lactate levels of $2.5 \mathrm{mmol} / \mathrm{L}$ post-WU. In accordance to mean values, the athletes are thought to return to a base value within one hour. In the literature, the time to reach this level is generally reported to be between 30 and 60 minutes (Rahmini, 2005, p.362).

As the post-WU rest period increased, the HR values increased too after the $400 \mathrm{~m}$ swimming performance. The longer the rest period of the subjects' post-WU allowed for more effort to be exerted and eventually enhance 
their performance in the $400 \mathrm{~m}$. Thus, estimating that the higher HR values are related to higher effort exertion. These results serve to confirm earlier findings by Gouvea at al. They examined the effect of different rest period in the range of 0 to $16 \mathrm{~min}$ on the vertical jump. In their study, up to $0-3$ minutes of rest was found to decrease performance, and a period of 3-12 minutes had moderate effects, whereas an increase in performance has been observed when resting time increased up to 16 (Gouvea, Fernandes, César, Silva and Gomes, 2013, p.460).

Considering similar studies in the swimming literature, in Zochowski, Johnson and Sleivert $(2007$, p.203) study conducted of 5 female and 5 male subjects a total of 10 national team-level swimmers with an average age of 17 , they found that a 10-minute passive rest interval post-WU protocols were more effective than 45 minutes. They stated that $200 \mathrm{~m}$ swimming performance records were $1.48 \%$ higher. Similarly, West, Dietzig, Bracken and Cunningham (2013, p.175) observed an increase of $1.48 \%$ when they compared periods of 20 minutes and 45 minutes of passive rest on a $200 \mathrm{~m}$ swimming performance. Besides these two studies, when Neiva, Marques, Barbosa and Izquierdo (2017, p.82) examined 11 male swimming athletes with an age range of $16-18$, the determined a $1.12 \%$ improvement in $100 \mathrm{~m}$ free sprint performance after 10 minutes than 20 minutes of passive rest interval post-WU. The findings of these studies contradict the results of this study. That may be due to the age differences, the shorter training experience of the subjects in our sample group or the difference in swimming distance.

Different rest periods between 10-40 minutes post-WU do not affect the $50 \mathrm{~m}$ swimming performance. However, this situation differed when the swimming distance is longer. In other words, when the resting time after warming is increased to 40 minutes; $400 \mathrm{~m}$ swimming performance is increased. Accordingly, a higher performance resulted in a higher $400 \mathrm{~m}$ postswimming HR. In conclusion, post-WU rest time does not affect swimming performance short distances up to $50 \mathrm{~m}$. However, as the swimming distance increases, a longer rest period has shown to improve performance.

Twenty male athletes between the age of 13 and 15 years old voluntarily participated in the study. Future studies can investigate the performance of swimmers of higher age groups. It might be better to investigate the effect of 
resting periods on performance by dividing them into more specific intervals.

\section{References}

Agopyan, A., Bozdoğan, F.S., Tekin, D., Küçük Yetkin, M. and Gün Güler C. (2012). Acute effects of static stretching exercises on short distance flutter kicking time in child swimmers. International Journal of Performance Analysis in Sport, 12, 484-497.

Alberti, G., Annoni, M., Ongaro, L., Scurati, R. and Michielon, G. (2014). Athletic performance decreases in young basketball players after Sitting. International Journal of Sports Science \& Coaching, 9, 975-84.

Ballionis, G., Nepocatych, S., Ellis, C.M., Richardson, M.T., Neggers, Y.H. and Bishop, P. A. (2012). Effects of different types of warm-up on swimming performance, reaction time and dive distance. Journal of Strength and Conditioning Research, 33, 483-498.

Coskun H. (2017). Genç yetiskinlerde setler arası farklı dinlenme aralıgı surelerinin kuvvet antrenmaninda sergilenen tekrar sayısına etkisi. Selcuk Universitesi, Saglık Bilimleri Enstitusu, Konya.

Eyuboglu, E. (2015). Judo müsabakaları arası optimum dinlenme süresinin saptanması. Ankara Üniversitesi Sağlık Bilimleri Enstitüsü. Ankara.

Galazoulas, C., Tzimou, A., Karamousalidis, G. and Mougios, V. (2012). Gradual decline in performance and changes in biochemical parameters of basketball players while resting after warm-up. European Journal of Applied Physiology, 112, 27-34.

Gouvêa, A., Fernandes, I., César, E., Silva, W. and Gomes, P. (2013).The effects of rest intervals on jumping performance: A meta-analysis on postactivation potentiation studies. Journal of Sports Sciences, 31, 459-467

Gunay, M. and Yuce, A. İ. (2008). The scientific foundations of football training. (Enhanced 3rd edition). Ankara: Gazi Kitapevi, p.223-343

Hedrick, A. (1992). Physiological responses to warm up. National Strength and Conditioning Journal, 14, 25-27.

Kuter, M. and Öztürk, F. (1997). Antrenör ve sporcu el kitabı. Bursa: Bağırgan Yayınevi, 34-67.

Neiva, H. P., Marques, M. C., Barbosa, T. M. and Izquierdo, M et al. (2017). Effects of $10 \mathrm{~min}$ vs. $20 \mathrm{~min}$ passive rest after warm-up on $100 \mathrm{~m}$ freestyle time-trial performance: A randomized crossover study. Journal of Science and Medicine in Sport, 20, 81-86. 
Rahmini, R. (2005). Effect of different rest intervals on the exercise volume completed during squat bouts. Journal of Sports Science and Medicine, 4, 361366.

Ryan, P., Lowery, M.N, Duncan J. and Loenneke, P. (2012). The effects of potentiating stimuli intensity under varying rest periods on vertical jump performance and power. The Journal of Strength and Conditioning Research, 26, 320-325.

Sahlin, K. (1992). Metabolic factors in fatigue. Sports Med. 13, 99-107.

Sevim, Y. (2007). Antrenman bilgisi. 7. Baskı. Ankara: Nobel Yayın Dağıım, p.295-297.

Smith, C. A. (2004). The warm up procedure: To stretch a brief review. The journal of Orthopaedic and Sports Physical Therapy, 19, 12-17

Turkmen, D. (2019). Aktif dinlenme sürelerinin tekrarl maksimal yüzme performanslarnna etkisi. Dokuz Eylul Üniversitesi, Saglık Bilimleri Enstitüsü, İzmir.

West, D. J., Dietzig, B. M., Bracken, R. M. and Cunningham, D. J. et. al. (2013). Influence of post-warm-up recovery time on swim performance in international swimmers. Journal of Science and Medicine in Sport, 16, 172176.

Woods, K., Biskop, P. and Jones, E. (2007). Warm up and stretching in the prevention of muscular injury. Sports Medicine, 37, 1089-1099.

Zochowski, T., Johnson, E. and Sleivert, G. G. (2007). Effects of varying postwarm-up recovery time on $200 \mathrm{~m}$ time-trial swim performance. Int $J$ Sports Physiol Perform, 2, 201-211.

\section{Citation Information}

İnanç, Y., Atan, T., and Ünver, Ş. (2021). Does rest period after warming up have an effect on swimming performance?. OPUSInternational Journal of Society Studies, 18(44), 7423-7434. DOI:10.26466//opus.951294. 